\title{
Influence of Irrigation with Saline Water on Yield and Nutrients Uptake of Wheat Plant Grown in Sandy and Sandy Loam Soils
}

\author{
Hussein Kh. Ahmed ${ }^{1}$, Hassan A. Fawy and G.Y.EL-Nagar ${ }^{2}$
}

\begin{abstract}
This study was carried out using two soil types of West Delta region, Egypt, at El-Bostan (sandy soil) and North El-Tahrir (sandy loam soil). A two-pot experiment at greenhouse had done through two years 2006 and 2007. The saline irrigation water consists of $\mathrm{NaCl}, \mathrm{CaCl}_{2}$ and their mixture (1:1), and added them by 4 doses, $(0,0.1,0.2$, 0.3 and $0.4 \mathrm{M} / \mathrm{L}$ ). The aim of this study attained the effect of irrigation with saline water on nutrients uptake and production of wheat (Triticum aestivum L.) Sakha8.

The obtained results indicated when increase levels of salts in irrigation water, soil $\mathrm{pH}$ and $\mathrm{EC}$ had positively increased, while the nutrients available in soils or uptake were decrease. Therefore, the plant growth and production of wheat had decreased. The $\mathrm{NaCl}$ salt had the highest negative effect on nutrients uptake and production of wheat, and $\mathrm{CaCl}_{2}$ salt had the lowest, while the mixture salts had moderate effect. The suitable level range of $\mathrm{NaCl}$ salt was 0.1-0.2M/L and 0.1-0.3M/L for $\mathrm{CaCl}_{2}$ salt, which achieved economic yield of wheat. The critical level of salinity was $0.3 \mathrm{M} / \mathrm{L}$ of $\mathrm{NaCl}$ salt and $0.4 \mathrm{M} / \mathrm{L}$ of $\mathrm{CaCl}_{2}$ salt, which caused high decrease in yield and damage in soil properties. The grain yields of wheat at rate $0.4 \mathrm{M} / \mathrm{L}$ of $\mathrm{NaCl}$ and $\mathrm{CaCl}_{2}$ was 0.33 and $0.51 \mathrm{Ton} / \mathrm{Fed}$ respectively, while it was 1.36 Ton/Fed at the control treatment.
\end{abstract}

\section{INTRODUCTION}

The most important factor threatening agricultural land is salinity. Water of $\mathrm{EC}<0.75 \mathrm{dS} / \mathrm{m}$ has no detrimental, $0.75-1.5 \mathrm{dS} / \mathrm{m}$ was detrimental effect on sensitive crops, $1.5-3.0 \mathrm{dS} / \mathrm{m}$ was require careful management practices, and 3.0-7.5 dS/m was used only for salt tolerant plants (Gary and Delno 2004). Plant growth and dry-matter decreased by increasing application doses of $\mathrm{NaCl}, \mathrm{NaNO}_{3}, \mathrm{Na}_{2} \mathrm{SO}_{4}$ and mixture salts. The $\mathrm{NaCl}$ had the highest negative effect on drymatter, but $\mathrm{Na}_{2} \mathrm{SO}_{4}$ had the lowest, (Aydin et al 2001). Vijay et al. (2006) reported that increasing salinity reduced yield of sugarcane. El-Agrodi et al (2005) showed that raising soil salinity level from (0-0.2\%) caused an increase in root dry weight, while soil salinity levels above $0.2 \%$ had high significantly decrease on root dry weight.

Concerning to effect of salinity on behavior of nutrients uptake Aydin et al (2001) observed that saline water with high $\mathrm{Na}$ content decreased $\mathrm{K}$ content in wheat plants. $\mathrm{N}, \mathrm{P}, \mathrm{Mn}, \mathrm{Zn}$ and $\mathrm{Cu}$ content of plants increased by increasing doses of Na-salts with $0.5 \% \mathrm{Na}$ salts and generally decreased after that. Mass (1988) stated that wheat is a tolerant crop. Alice et al (2002) stressed that excess salt increases the osmotic pressure of the soil water and produce conditions that keep the roots from absorbing water and nutrients. The objective of this study achieved economic yield of wheat (Sakha8) under irrigated of different saline water in recently reclaiming soils conditions of West Delta.

\section{MATERIALS AND METHODS}

Two pot experiments were conducted in greenhouse at the El-Bostan as sandy soils and North El-Tahrir as sandy loam soils during 2006 and 2007 years. Wheat variety (Triticum aestivum L.) was Sakha8. The used soils were collected from $0-30 \mathrm{~cm}$ depth, air-dried, and passed through $2 \mathrm{~mm}$-sieves. Twenty-kg of each soil were placed in a plastic pot $(33 \mathrm{~cm}$ height and $24 \mathrm{~cm}$ wide diameter). $\mathrm{P}$ as superphosphate $\left(8 \mathrm{gP}_{2} \mathrm{O}_{5} / \mathrm{pot}\right)$ added to each pot thoroughly mixed with the soil during seedbed preparation. The amount applied of $\mathrm{N}$ as (NH4) ${ }_{2} \mathrm{SO}_{4}$ and $\mathrm{K}$ as $\mathrm{K}_{2} \mathrm{SO}_{4}$ were 10 and $4 \mathrm{~g}$ for each pot respectively, and applied their three equal doses after 15,30 and 75 days from sowing. Seeds of wheat were sown in each pot as randomized application and then soil in each pot was irrigated with enough water to keep wet enough to sustain a satisfactory seed germination.

The uses of salts were $\mathrm{NaCl}, \mathrm{CaCl}_{2}$ and their mixtures as ratio (1:1). The levels of each salt were 0.1 , $0.2,0.3$, and $0.4 \mathrm{M} / \mathrm{L}$, which applied with irrigation water. The EC values of saline water were $2.35,4.73$, 7.13 and $9.45 \mathrm{dS} / \mathrm{m}$ for rates of $\mathrm{NaCl}$ salt, 1.86, 2.52, 3.78 and $5.28 \mathrm{dS} / \mathrm{m}$ for rates of $\mathrm{CaCl}_{2}$ salt, and 2.18 , $3.75,5.56$ and $7.48 \mathrm{dS} / \mathrm{m}$ for rates of mixed salt respectively. The EC of control water was $0.55 \mathrm{dS} / \mathrm{m}$. The saline water initial used at seedling emergence, after 3 days of planting. The plant samples had collected at three growth stages. The first sample was taken 15 days after emergence as whole plants (stage ${ }^{1}$ ). The second sample was taken 30 days from sowing $\left(\right.$ stage $^{2}$ )., while the third sample was taken at harvest time $\left(\right.$ stage $\left.^{3}\right)$. At the end of each experiment, the biological yield, grain, straw, 1000-grain weight, and number and weight of

\footnotetext{
${ }^{1}$ Soils and Water Dept., Faculty of Agric., Al-Azhar Univ. 2 Soil Fertility and Microbiology Dept., Desert Research Center (DRC), Cairo

Received April 10, 2008, Accepted May 4, 2008
} 
Table 1. Chemical and physical soil properties and available nutrients in the EI Boston and North El-Tahrir soils

\begin{tabular}{|c|c|c|c|c|c|c|c|c|}
\hline $\begin{array}{c}\text { Soil } \\
\text { Properties }\end{array}$ & El Boston & $\begin{array}{c}\text { North } \\
\text { El-Tahrir }\end{array}$ & $\begin{array}{l}\text { Soluble } \\
\text { ions*** }\end{array}$ & El Boston & $\begin{array}{c}\text { North } \\
\text { El-Tahrir }\end{array}$ & $\begin{array}{c}\text { Available } \\
\text { nutrients } \\
\text { (ppm) }\end{array}$ & El Boston & $\begin{array}{c}\text { North } \\
\text { El-Tahrir }\end{array}$ \\
\hline pH $* * *$ & 7.71 & 7.96 & $\mathrm{Na}$ & 1.08 & 1.53 & $\mathrm{~N}$ & 19.4 & 35.1 \\
\hline$E C d S / m^{* * * *}$ & 0.56 & 0.72 & K & 0.38 & 0.4 & $\mathrm{P}$ & 1.74 & 4.5 \\
\hline OM\% & 0.58 & 2.13 & $\mathrm{Ca}$ & 1.96 & 2.39 & K & 32 & 69 \\
\hline $\mathrm{CaCO}_{3} \%$ & 2.26 & 14.7 & $\mathrm{Mg}$ & 2.18 & 2.91 & $\mathrm{Fe}$ & 1.12 & 3.74 \\
\hline C.E.C* & 2.23 & 14.69 & $\mathrm{CO}_{3}$ & 0 & 0 & $\mathrm{Mn}$ & 0.84 & 1.84 \\
\hline Sand\% & 94.13 & 68.13 & $\mathrm{HCO}_{3}$ & 0.75 & 0.6 & $\mathrm{Zn}$ & 0.23 & 0.83 \\
\hline Silt \% & 5.45 & 14.51 & $\mathrm{Cl}$ & 4.3 & 5 & $\mathrm{Cu}$ & 0.08 & 0.31 \\
\hline Clay \% & 0.42 & 17.36 & $\mathrm{SO}_{4}$ & \multirow[t]{2}{*}{0.56} & 1.62 & & & \\
\hline Texture & $\mathrm{S}$ & S.L & & & & & & \\
\hline $\begin{array}{l}(*) \text { C.E.C (me } / 100 \mathrm{~g} \\
\text { spikes per squa } \\
\text { The experime } \\
\text { randomized fac } \\
\text { three replicated } \\
\text { variance (ANC }\end{array}$ & $\begin{array}{l}\text { il), }\left({ }^{* *}\right) \text { Solul } \\
\text { meter wer } \\
\text { al design } \\
\text { rial design }\end{array}$ & $\begin{array}{l}\text { le cations and } \\
\text { recorded i } \\
\text { used wo } \\
\text { vith three sa }\end{array}$ & $\begin{array}{r}\text { ions in soi } \\
\text { both sea } \\
\text { comp } \\
\text { s and co }\end{array}$ & $\begin{array}{ll}\text { me/L }), & (* * *) \\
\text { ons. } & \text { m } \\
\text { tely } & \text { wa } \\
\text { trol, } & \text { At } \\
\text { s of } & \text { Or } \\
\text { the } & \text { de }\end{array}$ & $\begin{array}{l}\text { luble water } 1 \text { : } \\
\text { dified by } B \\
\text { determine } \\
\text { iilable pot }\end{array}$ & $\begin{array}{l}\text { Osef and A } \\
\text { cording to } \\
\text { um was } \\
\text { an (1969). } \\
\text { ing to Lind }\end{array}$ & $\begin{array}{l}\text { (1978), an } \\
\text { teney and } \mathrm{n} \\
\text { termined } \\
\text { tvailable } \mathrm{n} \\
\text { and Norve }\end{array}$ & $\begin{array}{l}\text { available N } \\
\text { elson(1982). } \\
\text { ccording to } \\
\text { icronutrients } \\
1 \text { (1967). }\end{array}$ \\
\hline
\end{tabular}
differences among the treatments were significant or not (Gomez and Gomez 1984).

Soil mechanical analysis was achieved on the original soil samples prior sowing and soil texture was defined according to Piper(1950). Regarding soil chemical analysis, soil $\mathrm{pH}$ and EC and soluble cations and anions were achieved according to Jackson(1973),organic matter and CEC were determined according to Page et at(1984), available $\mathrm{P}$ was determined according to Watanabe and Olsen (1965) as

\section{RESULTS AND DISCUSSIONS}

Effect of saline water on soil properties and available nutrients in soils:

Figures 1 and 2 showed that available nutrients in the two soils were significantly decreased with increasing rates of salts under conditions of greenhouse pots at two years, while the exchangeable $\mathrm{Na}$ increased by increase rates of $\mathrm{NaCl}$ salt application.

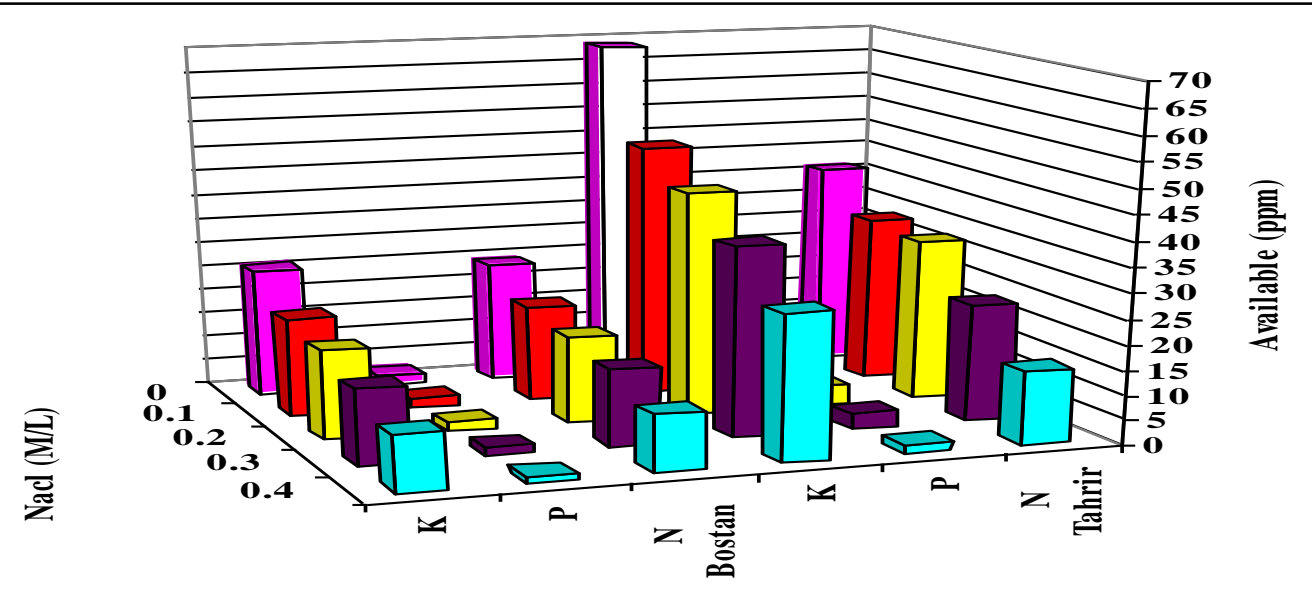

Fig 1. Effect of saline water $(\mathrm{NaCl})$ on available macronutrients of soil studies 


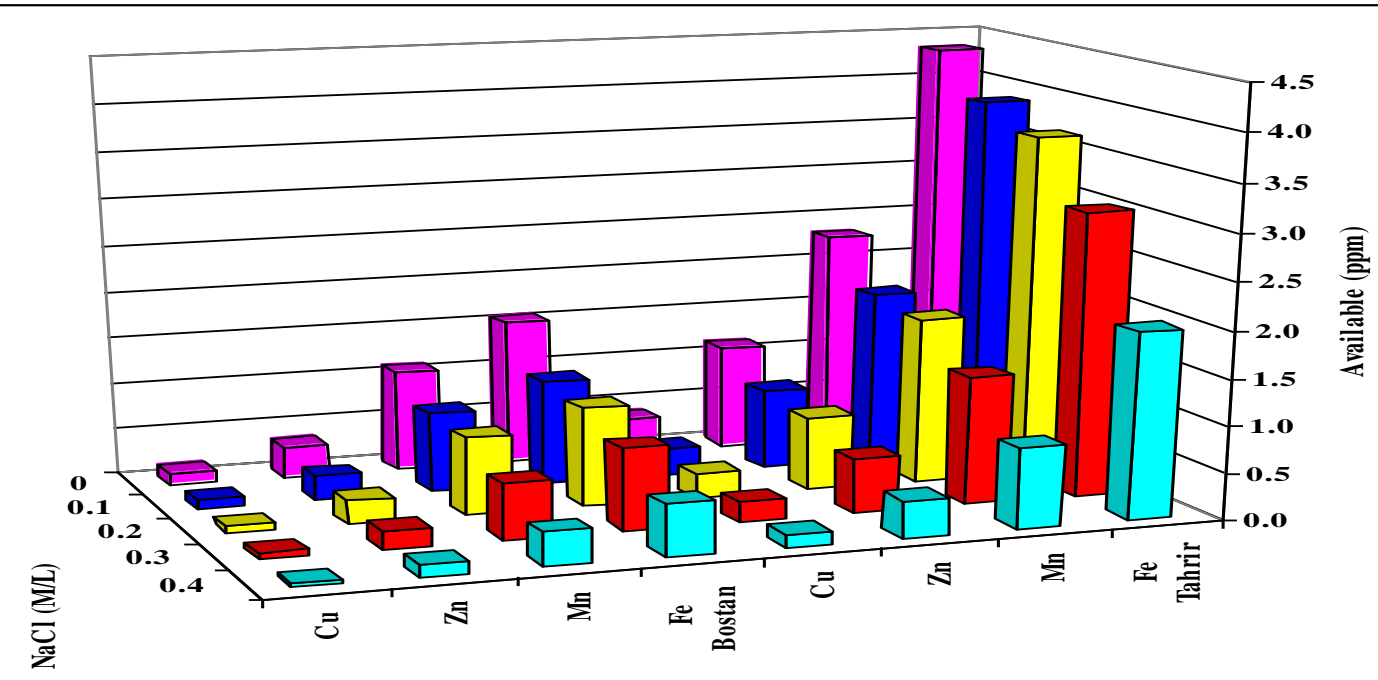

\section{Fig 2. Effect of water saline $(\mathrm{NaCl})$ on available micronutrients of soil studies}

The $\mathrm{NaCl}$ salt showed highest adverse effect on available nutrients, and $\mathrm{CaCl}_{2}$ salt had the lowest, while the mixture salt had moderately effect between them. The results obtained assure that the critical level of salinity was $0.3 \mathrm{M} / \mathrm{L}$ of $\mathrm{NaCl}$ salt and $0.4 \mathrm{M} / \mathrm{L}$ of $\mathrm{CaCl}_{2}$ salt, which caused higher decrease in yield parameters of wheat, while decreased of available nutrients and damage in soil properties when comparison with other levels of salts. The results obtained revealed that the sandy loam soil was highly affected by saline water than sandy soils. This could be due to the sandy soil contains lowest in clay content, while it was higher in filtration than sandy loam soil. The obtained results agree with those obtained by Aydin et al (2001).

Table (2) showed that $\mathrm{NaCl}$ had the highest effective on EC than other salts at two soils. The EC values generally increased with increasing rates of salts during different stage of wheat growth. Figure (3) revealed that the sand soils had lower EC values than sand loam soil. The results obtained reveal that the greater ability of $\mathrm{NaCl}$ prevented available nutrients to the plants than $\mathrm{CaCl} 2$ salt. These assure that importance of known type and concentration salt in saline water before using it. Our obtained results agree with those found by Gary and Delno (2004).

Table 2. Effect of water saline on EC during stages of wheat growth

\begin{tabular}{|c|c|c|c|c|c|c|c|}
\hline \multirow{4}{*}{ Salts } & \multirow{4}{*}{ 岕 } & \multicolumn{3}{|c|}{ Sand loam soil } & \multicolumn{3}{|c|}{ Sand soil } \\
\hline & & \multicolumn{6}{|c|}{ Stages of wheat } \\
\hline & & 1 & 2 & 3 & 1 & 2 & 3 \\
\hline & & \multicolumn{6}{|c|}{ E.C dS/m } \\
\hline Control & 0 & 0.72 & 0.96 & 1.17 & 0.56 & 0.73 & 0.95 \\
\hline \multirow{4}{*}{$\begin{array}{l}\bar{\Xi} \\
\bar{Z}\end{array}$} & 0.1 & 4.5 & 5.8 & 7.2 & 3.3 & 4.2 & 5.3 \\
\hline & 0.2 & 7.2 & 9.4 & 12.0 & 5.0 & 6.6 & 8.6 \\
\hline & 0.3 & 9.6 & 12.1 & 15.1 & 6.8 & 8.6 & 10.9 \\
\hline & 0.4 & 12.7 & 14.6 & 16.4 & 9.1 & 10.5 & 11.9 \\
\hline \multirow{4}{*}{$\underbrace{\pi}_{\tilde{J}}$} & 0.1 & 2.8 & 3.5 & 4.3 & 2.0 & 2.5 & 3.1 \\
\hline & 0.2 & 3.5 & 4.4 & 5.5 & 2.5 & 3.2 & 4.0 \\
\hline & 0.3 & 5.7 & 7.1 & 8.7 & 4.2 & 5.1 & 6.4 \\
\hline & 0.4 & 6.7 & 8.5 & 10.7 & 4.9 & 6.2 & 7.9 \\
\hline \multirow{4}{*}{ 总 } & 0.1 & 3.8 & 4.8 & 5.9 & 2.8 & 3.5 & 4.3 \\
\hline & 0.2 & 6.1 & 7.6 & 9.5 & 4.5 & 5.6 & 7.1 \\
\hline & 0.3 & 7.8 & 9.7 & 12.0 & 5.6 & 7.0 & 8.8 \\
\hline & 0.4 & 10.0 & 11.9 & 13.8 & 7.3 & 8.6 & 10.2 \\
\hline
\end{tabular}




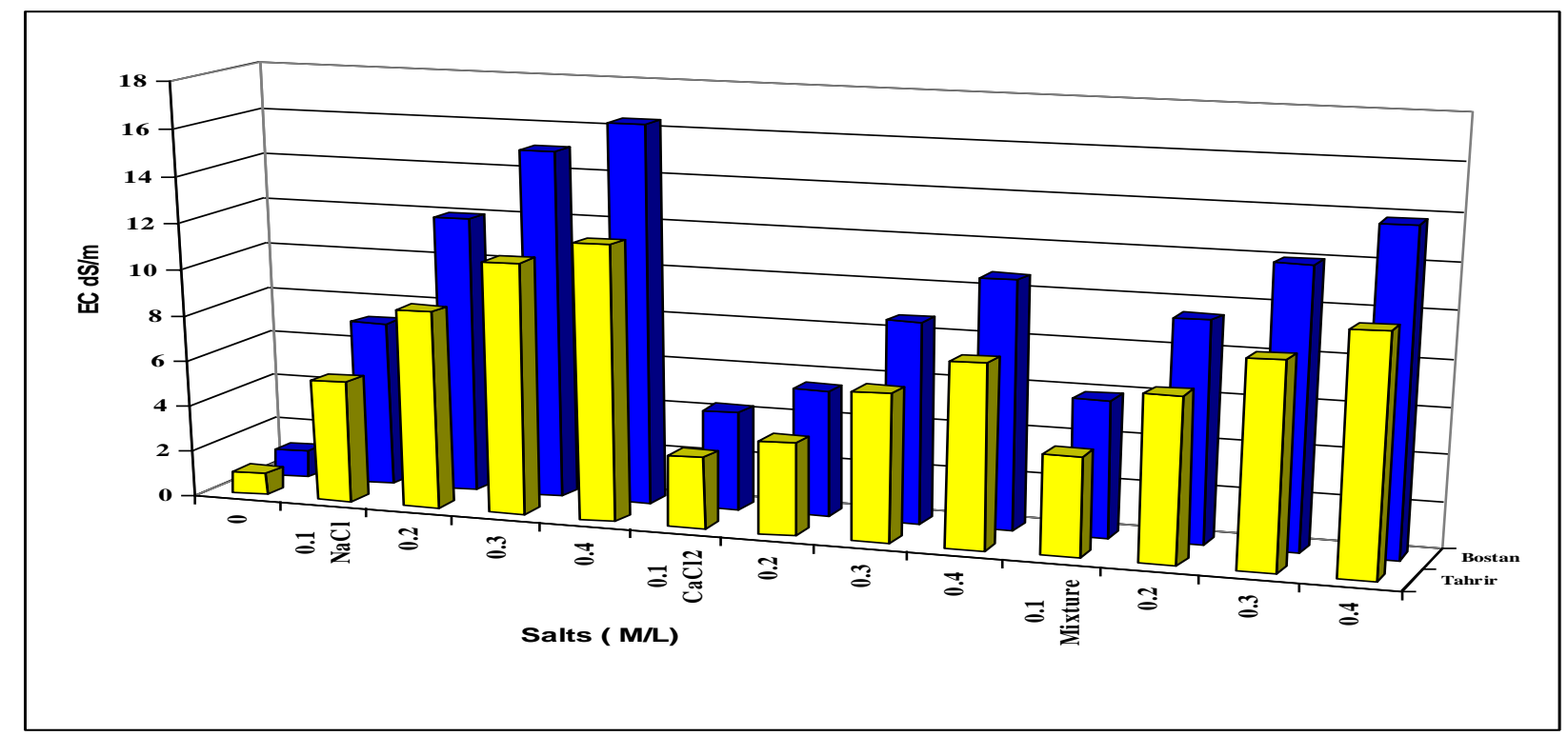

Fig 3. Effect of water saline on EC during harvest stage of wheat in soils

Effect of saline water on yield parameters of wheat:

The levels of salts had significant effect on yield of wheat as the following in Table (3).

Table 3. Effects of saline water on yield components of wheat

\begin{tabular}{|c|c|c|c|c|c|c|c|}
\hline \multirow{3}{*}{ Salts } & \multirow{3}{*}{$\frac{\frac{\text { Levels }}{\mathrm{M} / \mathrm{L}}}{\underline{\underline{n}}}$} & \multicolumn{3}{|c|}{ Yield (g/pot.) } & Weight & \multicolumn{2}{|c|}{ spikes/m2 } \\
\hline & & bio & Straw & grain & $1000(\mathrm{~g})$ & W. Kg & No. \\
\hline & & \multicolumn{6}{|c|}{ Sandy soil } \\
\hline Control & 0 & 69.3 & 46.9 & 22.5 & 33.9 & 0.38 & 208 \\
\hline \multirow[t]{4}{*}{$\mathrm{NaCl}$} & 0.1 & 58.8 & 40.4 & 18.4 & 29.2 & 0.3 & 195 \\
\hline & 0.2 & 49.8 & 34.6 & 15.2 & 23.4 & 0.26 & 171 \\
\hline & 0.3 & 34.3 & 23.2 & 11.1 & 20.3 & 0.2 & 153 \\
\hline & 0.4 & 25.8 & 18.6 & 6.2 & 15.4 & 0.17 & 141 \\
\hline \multirow{4}{*}{$\mathrm{CaCl}_{2}$} & 0.1 & 63.2 & 42.7 & 20.5 & 30.7 & 0.33 & 200 \\
\hline & 0.2 & 51.7 & 35.3 & 16.4 & 26.7 & 0.29 & 193 \\
\hline & 0.3 & 44.2 & 30.4 & 13.8 & 21.6 & 0.23 & 181 \\
\hline & 0.4 & 32.6 & 21.6 & 9.5 & 17.3 & 0.2 & 162 \\
\hline \multirow[t]{4}{*}{ Mixture } & 0.1 & 61 & 41.6 & 19.5 & 30 & 0.32 & 198 \\
\hline & 0.2 & 50.8 & 35 & 15.8 & 25.1 & 0.28 & 182 \\
\hline & 0.3 & 39.3 & 26.8 & 12.5 & 21 & 0.22 & 167 \\
\hline & 0.4 & 29.2 & 20.1 & 9.1 & 16.4 & 0.19 & 152 \\
\hline \multicolumn{2}{|c|}{ LSD.05 } & 0.3 & 0.2 & 0.1 & 0.1 & 0.01 & 0.5 \\
\hline \multicolumn{2}{|c|}{ Sig. } & $* * *$ & $* * *$ & **** & $* * *$ & $* * *$ & $* * *$ \\
\hline \multicolumn{8}{|c|}{ Sandy loam soil } \\
\hline Control & 0 & 105.5 & 72.6 & 32.9 & 45.2 & 0.72 & 250 \\
\hline \multirow[t]{4}{*}{$\mathrm{NaCl}$} & 0.1 & 89.1 & 63.5 & 25.6 & 38.6 & 0.6 & 240 \\
\hline & 0.2 & 75.1 & 55.7 & 19.4 & 30.3 & 0.51 & 220 \\
\hline & 0.3 & 57 & 43.4 & 13.6 & 24.3 & 0.41 & 205 \\
\hline & 0.4 & 38.7 & 32.5 & 7.2 & 19.7 & 0.32 & 181 \\
\hline \multirow[t]{4}{*}{$\mathrm{CaCl}_{2}$} & 0.1 & 94.1 & 65.3 & 28.8 & 40.3 & 0.62 & 242 \\
\hline & 0.2 & 85.8 & 60.6 & 25.2 & 33.1 & 0.55 & 228 \\
\hline & 0.3 & 72.2 & 51.7 & 20.5 & 26.9 & 0.44 & 210 \\
\hline & 0.4 & 47.8 & 38.3 & 11 & 21.9 & 0.34 & 198 \\
\hline \multirow[t]{4}{*}{ Mixture } & 0.1 & 91.6 & 64.4 & 27.2 & 39.5 & 0.61 & 241 \\
\hline & 0.2 & 80.5 & 58.2 & 22.3 & 31.7 & 0.53 & 224 \\
\hline & 0.3 & 64.6 & 47.6 & 17.1 & 25.6 & 0.43 & 208 \\
\hline & 0.4 & 43.3 & 35.4 & 9.5 & 20.8 & 0.33 & 190 \\
\hline \multicolumn{2}{|c|}{ LSD.05 } & 0.5 & 0.3 & 0.2 & 0.2 & 0.03 & 0.5 \\
\hline \multicolumn{2}{|c|}{ Sig. } & $* * *$ & $* * *$ & $* * *$ & $* * *$ & $* * *$ & $* * *$ \\
\hline
\end{tabular}

Bio (Biological), W. Kg (Weight spikes by Kg), No (Number of spikes) 
The yield parameters were reduced by increasing rates of salts applied to soil. The suitable level range was $0.1-0.3 \mathrm{M} / \mathrm{L}$ of $\mathrm{NaCl}$ salt and $0.1-0.2 \mathrm{M} / \mathrm{L}$ of $\mathrm{CaCl}_{2}$ salt, which produce economic yield of wheat under conditions of irrigation by saline water at two soils. The higher levels over above ranges caused damage in soil properties and yield production. The $\mathrm{NaCl}$ salt at level $0.4 \mathrm{M} / \mathrm{L}$ gave significantly higher decrease in biological, straw and grain yields of wheat when compared with control treatment by 63,58 and $75 \%$ respectively, analogously the $\mathrm{CaCl}_{2}$ salt decreased by 54,51 and $62 \%$ for the same yield parameters of wheat during 2 seasons.
The obtained results go with those obtained by ElAgrodi et al (2005).

Figures 4 and 5 showed that, the grain and straw yield were generally decreased with increasing salts levels. The sandy loam soil attained much higher increase yield parameters of wheat when compared with sandy soil by 18,19, 16, 12, 14 and $5 \%$ for biological, straw, grain, 1000-grain weight, and weight and number of spikes respectively during the two seasons (Table3). This attributed to the relatively higher nutrient supplying power of the sand loam soils. Davis et al. (2002) obtained similar results.

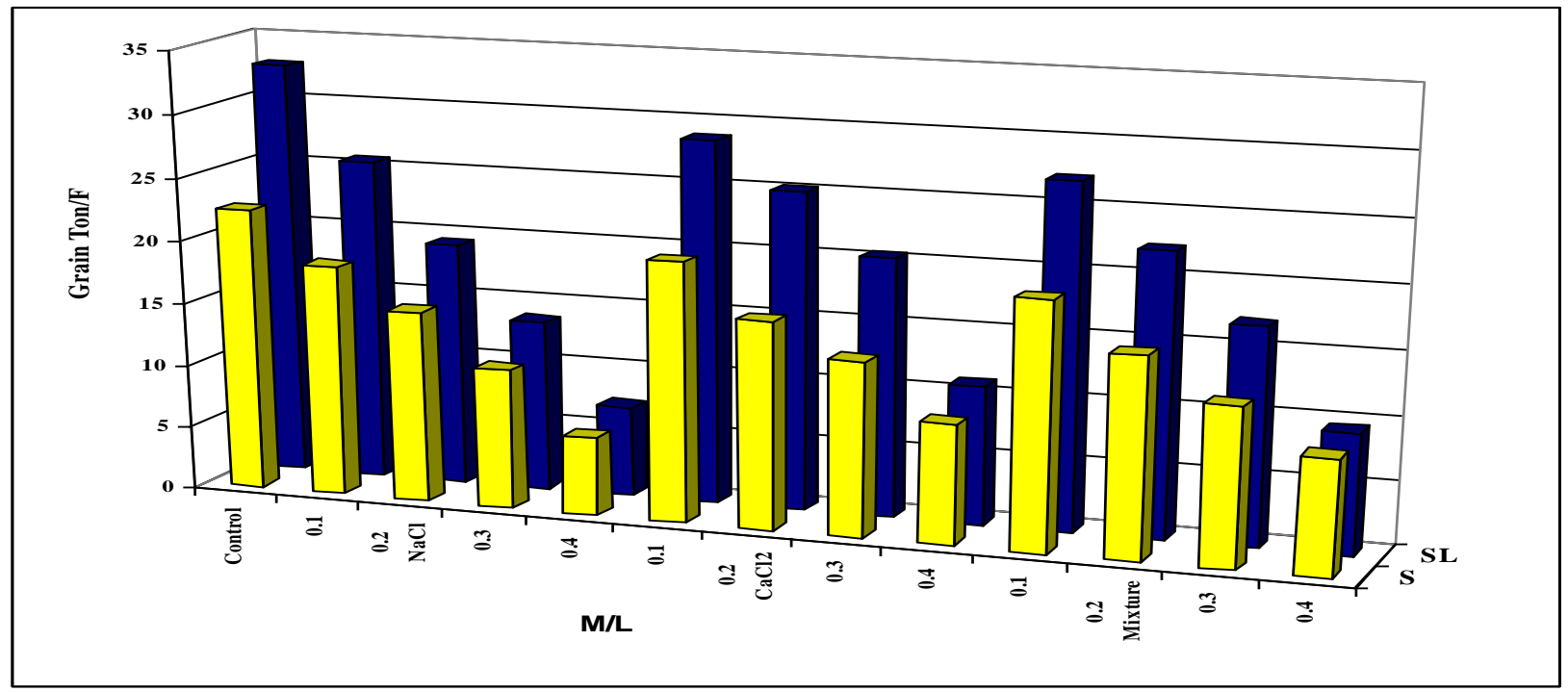

Fig 4. Effects of saline water irrigation on grain yield in soils

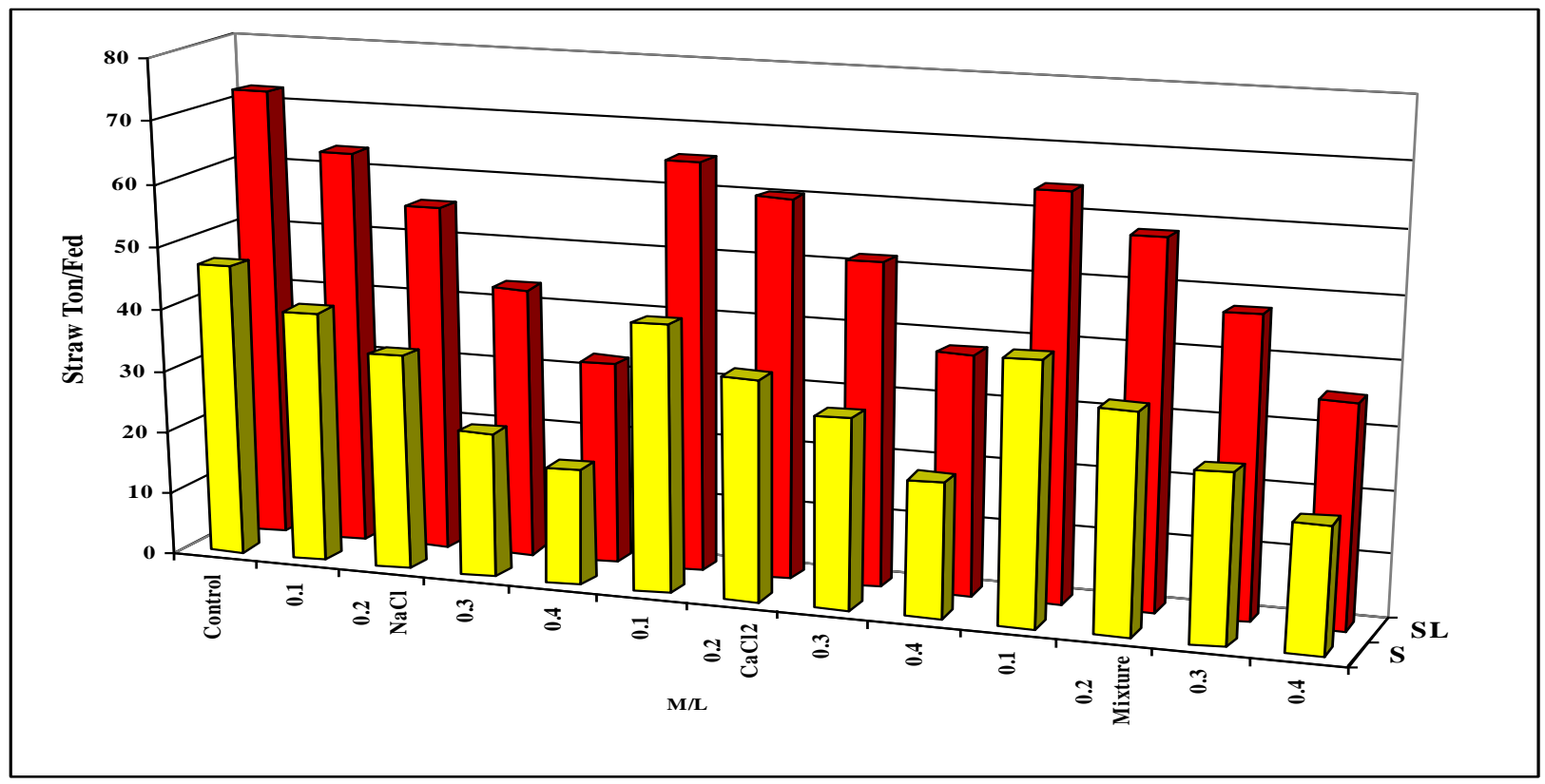

Fig. 5. Effects of saline water irrigation on straw yield in soils 
Effect of saline water on nutrients uptake by wheat:

Tables 4 and 5 showed that increasing rates of $\mathrm{NaCl}$ salt led to a decrease of $\mathrm{K}, \mathrm{N}, \mathrm{P}, \mathrm{Mn}, \mathrm{Zn}$ and $\mathrm{Cu}$ content in grain and straw at harvest stage of wheat. The plants treated by $\mathrm{CaCl} 2$ and mixtures salts had higher nutrients absorption than plants treated with $\mathrm{NaCl}$ salt through different rates of salts. The generally trends were decrease in dry matter of wheat by increasing salts levels at two soil and two seasons. The lowest nutrients uptake by plant was at the level $0.4 \mathrm{M} / \mathrm{L}$ of all salts, while the higher was at control. The results obtained revealed that higher $\mathrm{NaCl}$ salt caused low nutrients in plant tissues, when compared with $\mathrm{CaCl} 2$ salt, while the mixture salt was moderately effect between their. The critical level of salinity was $0.3 \mathrm{M} / \mathrm{L}$ of $\mathrm{NaCl}$ salt and $0.4 \mathrm{M} / \mathrm{L}$ of $\mathrm{CaCl} 2$ salt, which caused higher decrease of nutrients uptake by wheat than other levels of salts. This results goes with Gary and Delno (2004) found similar results that increasing rates of salts resulted in low nutrients in plant tissues. The obtained results indicated that sand texture soil was more ability to resistance the high salinity in irrigation water when comparison with the sandy loam soil. This results may be due to the sandy soil was higher filtration than sandy loam soil. The results obtained agree with and Davis et al. (2002).

In conclusion, the obtained results showed that the nutrients uptake by plant and yield parameters of wheat had negatively affected by increase rates of whole salts in irrigation water. The $\mathrm{NaCl}$ salt had the highest significantly effect on decreasing of available nutrients, nutrients uptake and wheat yield, while the $\mathrm{CaCl} 2$ salt was lowest.

The suitable levels ranges were $0.1-0.2 \mathrm{M} / \mathrm{L}$ of $\mathrm{NaCl}$ salt and $0.1-0.3 \mathrm{M} / \mathrm{L}$ of $\mathrm{CaCl}_{2}$ salt for produce economic yield of wheat at studied soils.

Table 4. Effect of water saline on nutrients uptake (mg/pot) at harvest stage of wheat

\begin{tabular}{|c|c|c|c|c|c|c|c|c|c|}
\hline \multirow{3}{*}{ Salts } & \multirow{3}{*}{ 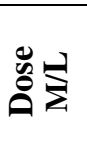 } & \multicolumn{2}{|c|}{$\mathbf{N}$} & \multicolumn{2}{|c|}{$\mathbf{P}$} & \multicolumn{2}{|c|}{$\mathbf{K}$} & \multicolumn{2}{|c|}{$\mathbf{N a}$} \\
\hline & & Straw & Grain & Straw & Grain & Straw & Grain & Straw & Grain \\
\hline & & \multicolumn{8}{|c|}{ Sand soil } \\
\hline Control & 0 & 183 & 317 & 70 & 63 & 582 & 113 & 86 & 60 \\
\hline & 0.1 & 134 & 207 & 51 & 40 & 422 & 78 & 184 & 120 \\
\hline $\bar{U}$ & 0.2 & 92 & 136 & 35 & 25 & 288 & 54 & 167 & 99 \\
\hline$\tilde{z}$ & 0.3 & 42 & 78 & 16 & 13 & 135 & 35 & 127 & 76 \\
\hline & 0.4 & 19 & 35 & 8 & 5 & 62 & 19 & 77 & 48 \\
\hline & 0.1 & 154 & 269 & 60 & 53 & 483 & 98 & 91 & 60 \\
\hline$\tilde{U}$ & 0.2 & 109 & 179 & 44 & 33 & 348 & 71 & 85 & 51 \\
\hline שֶ & 0.3 & 71 & 131 & 28 & 23 & 227 & 55 & 67 & 47 \\
\hline & 0.4 & 35 & 77 & 14 & 13 & 112 & 34 & 49 & 33 \\
\hline$\exists$ & 0.1 & 146 & 231 & 54 & 44 & 458 & 85 & 142 & 94 \\
\hline$=$ & 0.2 & 97 & 157 & 37 & 30 & 309 & 62 & 129 & 79 \\
\hline 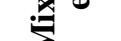 & 0.3 & 57 & 101 & 23 & 17 & 183 & 44 & 106 & 67 \\
\hline & 0.4 & 29 & 58 & 10 & 9 & 91 & 28 & 76 & 49 \\
\hline \multicolumn{2}{|c|}{ LSD.05 } & 2.1 & 3.7 & 0.9 & 0.8 & 6.6 & 1.5 & 2.4 & 1.5 \\
\hline \multicolumn{2}{|c|}{ Sig. } & $* * *$ & $* * *$ & $* * *$ & $* * *$ & $* * *$ & $* * *$ & $* * *$ & *** \\
\hline \multicolumn{10}{|c|}{ Sand loam soil } \\
\hline Control & 0 & 537 & 721 & 167 & 158 & 1721 & 224 & 174 & 115 \\
\hline & 0.1 & 400 & 448 & 123 & 95 & 1273 & 148 & 318 & 149 \\
\hline $\bar{\sigma}$ & 0.2 & 300 & 268 & 95 & 54 & 959 & 97 & 317 & 157 \\
\hline$\tilde{z}^{\sigma}$ & 0.3 & 182 & 141 & 58 & 27 & 588 & 57 & 275 & 139 \\
\hline & 0.4 & 101 & 43 & 31 & 6 & 323 & 22 & 215 & 89 \\
\hline & 0.1 & 438 & 559 & 137 & 121 & 1391 & 179 & 168 & 108 \\
\hline$\tilde{v}^{2}$ & 0.2 & 376 & 436 & 115 & 93 & 1200 & 144 & 162 & 95 \\
\hline שֶ & 0.3 & 274 & 297 & 83 & 62 & 874 & 105 & 144 & 80 \\
\hline & 0.4 & 149 & 88 & 46 & 15 & 479 & 40 & 112 & 45 \\
\hline$\fallingdotseq$ & 0.1 & 412 & 485 & 125 & 105 & 1310 & 157 & 244 & 126 \\
\hline$E_{0}$ & 0.2 & 326 & 348 & 99 & 71 & 1049 & 118 & 242 & 136 \\
\hline 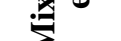 & 0.3 & 219 & 200 & 68 & 40 & 707 & 74 & 217 & 116 \\
\hline & 0.4 & 120 & 67 & 37 & 10 & 387 & 32 & 169 & 81 \\
\hline \multicolumn{2}{|c|}{ LSD.05 } & 6.6 & 7.3 & 2.1 & 1.5 & 20.7 & 2.5 & 4.5 & 2.3 \\
\hline \multicolumn{2}{|c|}{ Sig. } & $* * *$ & $* * *$ & $* * *$ & $* * *$ & $* * *$ & $* * *$ & $* * *$ & $* * *$ \\
\hline
\end{tabular}


Hussein Kh. Ahmed, Hassan A. Fawy,and G.Y.EL-Nagar: Influence of Irrigation with Saline Water on Yield and Nutrients Uptake ...

Table 5. Effect of water saline on nutrients uptake (mg/pot) at harvest stage of wheat

\begin{tabular}{|c|c|c|c|c|c|c|c|c|c|}
\hline \multirow{3}{*}{ Salts } & \multirow{3}{*}{ 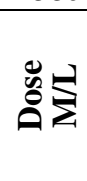 } & \multicolumn{2}{|c|}{$\mathbf{F e}$} & \multicolumn{2}{|c|}{ Mn } & \multicolumn{2}{|c|}{$\mathbf{Z n}$} & \multicolumn{2}{|c|}{$\mathrm{Cu}$} \\
\hline & & Straw & Grain & Straw & Grain & Straw & Grain & Straw & Grain \\
\hline & & \multicolumn{8}{|c|}{ Sandy soil } \\
\hline Control & 0 & 4.16 & 2.12 & 1.12 & 0.68 & 0.76 & 0.27 & 0.25 & 0.19 \\
\hline $\begin{array}{l}\bar{\Xi} \\
\bar{Z}\end{array}$ & $\begin{array}{l}0.1 \\
0.2 \\
0.3 \\
0.4\end{array}$ & $\begin{array}{l}3.01 \\
2.07 \\
0.97 \\
0.44\end{array}$ & $\begin{array}{l}1.34 \\
0.84 \\
0.45 \\
0.17\end{array}$ & $\begin{array}{l}0.81 \\
0.56 \\
0.26 \\
0.12\end{array}$ & $\begin{array}{l}0.43 \\
0.27 \\
0.14 \\
0.06\end{array}$ & $\begin{array}{l}0.55 \\
0.38 \\
0.18 \\
0.08\end{array}$ & $\begin{array}{l}0.17 \\
0.11 \\
0.06 \\
0.02\end{array}$ & $\begin{array}{l}0.19 \\
0.13 \\
0.06 \\
0.03\end{array}$ & $\begin{array}{l}0.12 \\
0.08 \\
0.04 \\
0.02\end{array}$ \\
\hline$\underbrace{ت}_{\tilde{J}}$ & $\begin{array}{l}0.1 \\
0.2 \\
0.3 \\
0.4\end{array}$ & $\begin{array}{l}3.45 \\
2.49 \\
1.64 \\
0.80\end{array}$ & $\begin{array}{l}1.76 \\
1.13 \\
0.80 \\
0.44\end{array}$ & $\begin{array}{l}0.93 \\
0.67 \\
0.44 \\
0.22\end{array}$ & $\begin{array}{l}0.56 \\
0.36 \\
0.25 \\
0.14\end{array}$ & $\begin{array}{l}0.63 \\
0.45 \\
0.30 \\
0.15\end{array}$ & $\begin{array}{l}0.23 \\
0.15 \\
0.10 \\
0.06\end{array}$ & $\begin{array}{l}0.21 \\
0.15 \\
0.10 \\
0.05\end{array}$ & $\begin{array}{l}0.16 \\
0.10 \\
0.07 \\
0.04\end{array}$ \\
\hline 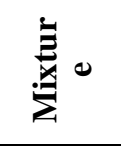 & $\begin{array}{l}0.1 \\
0.2 \\
0.3 \\
0.4 \\
\end{array}$ & $\begin{array}{l}3.27 \\
2.22 \\
1.31 \\
0.65 \\
\end{array}$ & $\begin{array}{l}1.50 \\
0.98 \\
0.60 \\
0.31 \\
\end{array}$ & $\begin{array}{l}0.88 \\
0.60 \\
0.35 \\
0.17 \\
\end{array}$ & $\begin{array}{l}0.48 \\
0.31 \\
0.19 \\
0.10 \\
\end{array}$ & $\begin{array}{l}0.59 \\
0.40 \\
0.24 \\
0.12 \\
\end{array}$ & $\begin{array}{l}0.19 \\
0.13 \\
0.08 \\
0.04 \\
\end{array}$ & $\begin{array}{l}0.20 \\
0.14 \\
0.08 \\
0.04 \\
\end{array}$ & $\begin{array}{l}0.14 \\
0.09 \\
0.05 \\
0.03 \\
\end{array}$ \\
\hline \multicolumn{2}{|c|}{ LSD.05 } & 0.05 & 0.02 & 0.01 & 0.01 & 0.01 & 0.01 & 0.01 & 0.01 \\
\hline \multicolumn{2}{|c|}{ Sig. } & $* * *$ & $* * *$ & $* * *$ & $* * *$ & $* * *$ & $* * *$ & $* * *$ & $* * *$ \\
\hline \multicolumn{10}{|c|}{ Sandy loam soil } \\
\hline Control & 0 & 12.85 & 6.18 & 2.83 & 1.59 & 2.69 & 0.87 & 0.76 & 0.53 \\
\hline $\begin{array}{l}\bar{Z} \\
\bar{Z}\end{array}$ & $\begin{array}{l}0.1 \\
0.2 \\
0.3 \\
0.4\end{array}$ & $\begin{array}{l}9.52 \\
7.16 \\
4.38 \\
2.42\end{array}$ & $\begin{array}{l}3.74 \\
2.15 \\
1.05 \\
0.25\end{array}$ & $\begin{array}{l}2.10 \\
1.58 \\
0.96 \\
0.53\end{array}$ & $\begin{array}{l}0.96 \\
0.55 \\
0.27 \\
0.07\end{array}$ & $\begin{array}{l}1.99 \\
1.50 \\
0.91 \\
0.51\end{array}$ & $\begin{array}{l}0.52 \\
0.30 \\
0.15 \\
0.04\end{array}$ & $\begin{array}{l}0.56 \\
0.42 \\
0.26 \\
0.14\end{array}$ & $\begin{array}{l}0.32 \\
0.18 \\
0.09 \\
0.02\end{array}$ \\
\hline$\Xi^{\pi}$ & $\begin{array}{l}0.1 \\
0.2 \\
0.3 \\
0.4\end{array}$ & $\begin{array}{c}10.40 \\
8.95 \\
6.51 \\
3.58\end{array}$ & $\begin{array}{l}4.73 \\
3.62 \\
2.39 \\
0.60\end{array}$ & $\begin{array}{l}2.29 \\
1.98 \\
1.44 \\
0.79\end{array}$ & $\begin{array}{l}1.22 \\
0.93 \\
0.62 \\
0.15\end{array}$ & $\begin{array}{l}2.17 \\
1.87 \\
1.36 \\
0.75\end{array}$ & $\begin{array}{l}0.67 \\
0.51 \\
0.34 \\
0.08\end{array}$ & $\begin{array}{l}0.61 \\
0.53 \\
0.38 \\
0.21\end{array}$ & $\begin{array}{l}0.40 \\
0.31 \\
0.20 \\
0.05\end{array}$ \\
\hline 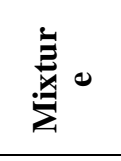 & $\begin{array}{l}0.1 \\
0.2 \\
0.3 \\
0.4 \\
\end{array}$ & $\begin{array}{l}9.80 \\
7.83 \\
5.29 \\
2.88 \\
\end{array}$ & $\begin{array}{l}4.06 \\
2.83 \\
1.56 \\
0.42 \\
\end{array}$ & $\begin{array}{l}2.16 \\
1.73 \\
1.17 \\
0.63 \\
\end{array}$ & $\begin{array}{l}1.04 \\
0.73 \\
0.40 \\
0.11 \\
\end{array}$ & $\begin{array}{l}2.05 \\
1.63 \\
1.10 \\
0.60 \\
\end{array}$ & $\begin{array}{l}0.57 \\
0.40 \\
0.22 \\
0.06 \\
\end{array}$ & $\begin{array}{l}0.57 \\
0.46 \\
0.31 \\
0.17\end{array}$ & $\begin{array}{l}0.05 \\
0.35 \\
0.24 \\
0.13 \\
0.04\end{array}$ \\
\hline \multicolumn{2}{|c|}{ LSD.05 } & 0.15 & 0.06 & 0.04 & 0.02 & 0.03 & 0.01 & 0.01 & 0.01 \\
\hline \multicolumn{2}{|c|}{ Sig. } & $* * *$ & $* * *$ & $* * *$ & $* * *$ & $* * *$ & $* * *$ & $* * *$ & $* * *$ \\
\hline
\end{tabular}

So that this studies recommended did not use saline water over above levels ranges of salts in both of studies soils, whereas the critical level of salinity was $0.3 \mathrm{M} / \mathrm{L}$ of $\mathrm{NaCl}$ salt and $0.4 \mathrm{M} / \mathrm{L}$ of $\mathrm{CaCl}_{2}$ salt, which it caused high decrease in yield and damage in soil properties. The sand loam soil was higher significantly increase of available nutrients, nutrients uptake and wheat yield than sand soils, this attributed to the relatively higher nutrient supplying power of the sand loam. The sand soils were lower of EC values than sand loam soils, this was due to the sand soils was lowest in clay content and highest filtration.

\section{REFERENCES}

Adil Aydin, Metin Turan, Yıldırım Sezen (2001) Effect of sodium salts on growth and nutrient uptake of spinach (Spinacia oleracea) and beans (Phaseolus vulgaris).
University of Atatürk, Faculty of Agriculture, Department of Soil Science, b 25240-Erzurum/Turkey.

Alice J. Jones, Bob Sorensen and Betsy Dierberger (2002) Soil and water resources. University of Florida, Institute of Food and Agricultural Sciences.

Bar-Yosef B and B. Akr (1978). Sodium Bicarbonate Extraction to estimate nitrogen, phosphorus and potassium availability in soils. Soil Sci. Soc. Am. J. 42: 319-323.

Davis, J.G., Westfall D.G, Mortvedt J.J and Shanahan J.F. (2002). Fertilizing winter wheat. Soil and Crop Sciences, Colorado State University.

El-Agrodi M.W.M., Labeeb G, Abd El-Hadi and.Abdou T.A.M (2005) Influence of soil salinity on CEC, growth and NPK content of wheat roots. J. Agric.Sci. Mansoura Univ., 30 (9) 5675-5687.

Gary W. Hergert and Delno Knudsen (2004) Irrigation Water Quality Criteria. Nebraska, Institute of Agriculture and Natural Resources. 
Gomez, K.A. and A.A. Gomez (1984). Statistical procedures for agricultural Res. 2n ed. Wiley, New York.

Jackson M.L.(1973).Soil chemical analysis. Printice Hall, Inc., Englewood cliffs, N.J.library of congress,USA.

Keeney D. R and D.W. Nelson (1982). Nitrogen Inorganic Forms. Pages 643-698. In A.L. Page et al., Eds. Methods of soil analysis. Part2. Agronomy No. 9, Amer. Soc. of Agron., Madison, WI.

Lindsay, W.L. and W.A. Norvell (1978). Development of DTPA soil test for zinc, iron, manganese and copper. Soil Sci. Soc. Am. Proc. 42: 421-428.

Mass, E. V. (1986) Salt tolerance of plants. App. Agric, Res., 1: $12-26$

Onyers, E.S. and E.O. McLean (1969). Plant uptake and chemical extractions for evaluating Potassium release characteristics of soils. Soil Sci. Soc. Amer. Proc. 33: 226230.

Page, A.L.; Miller, R.H. and Keeney, D.R. (1984). Methods of soil analysis. Part 2: Chemical and Microbiological Properties. Second edition. Agronomy J. 9: 2, Am. Soc. Agron. Inc., Soil Sci. Soc. Am. Inc. Pub. Madison, Wisconsin, USA.

Piper,C.S(1950)soil and plant analysis, $1^{\text {st }}$ Ed.Inter.publishers,New york,USA,47-79.

Vijay Shankar Mali1, Renuka Joshi1, Narayan Zende1, and Bansal S.K. (2006) Effect of Different Levels and Sources of Potassium on Yield and Quality of Sugarcane in Alkali Soil. Soil Science, Philadelphia, Pennsylvania, USA.

Watanabe, F.S. and S.R. Olsen (1956). Test of an ascorbic acid method for determining phosphorus in water and NaHCO3 extracts from soil . Soil Sci. Soc. Amer. Proc. 33: 226-230. 


\section{الملخص العربي}

\section{تأثير الرى بالماء المالح على امتصاص المغذيات وانتاجية نبات القمح النامى فى الاراضى الرملية}

\section{والرملية الطميية}

حسين خالد أمد، حسن عبد العاطي فاوي، جودة النجار

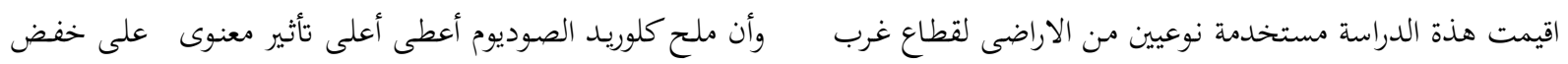

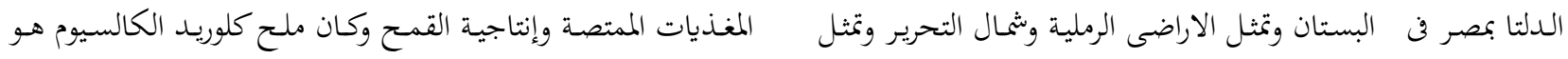

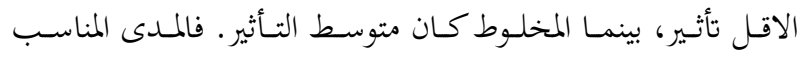

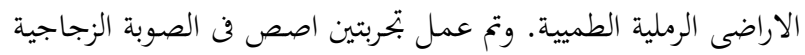

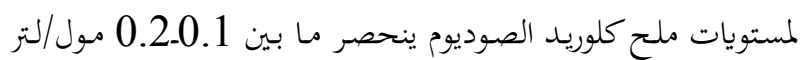

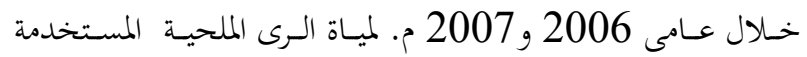

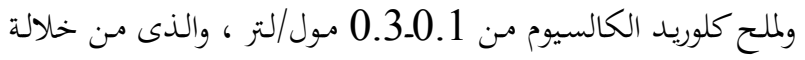
تتكـون مـن كلوريـد الصوديوم و كلوريـد الكالسيوم ومخلوط بينهما

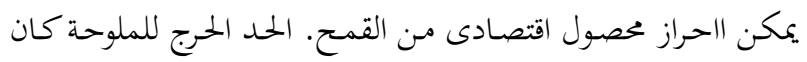
بنسبة(1:1) والتى تضاف بمستويات (صفر

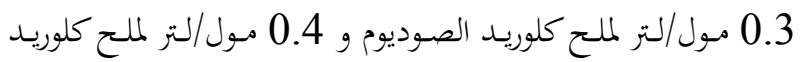
0.4 مول/لتز). والهدف من هذة الدراسة معرفة تأثير ماء الرى المالح

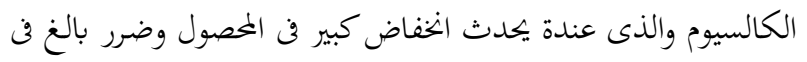
على امتصاص المغذيات وانتاجية خصول القمح(صنف سخا 8).

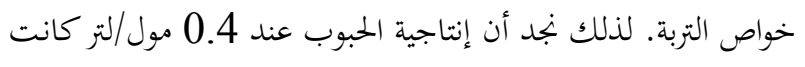

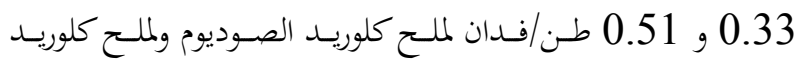

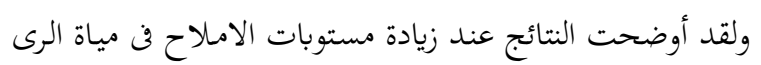

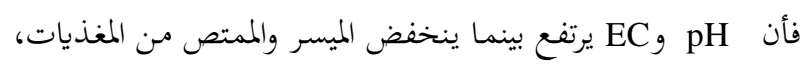

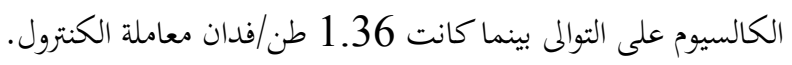

